\title{
Characterisation of insulin-like growth factor I receptor in skeletal muscles of normal and insulin resistant subjects
}

\author{
N. Livingston ${ }^{1}$, T. Pollare ${ }^{2}$, H. Lithell ${ }^{2}$ and P. Arner ${ }^{3}$ \\ ${ }^{1}$ Department of Medicine, University of Rochester, School of Medicine and Dentistry, Rochester, NY, USA, \\ ${ }^{2}$ Department of Geriatrics, Uppsala University, and the Kungsgärdet's Hospital, and \\ ${ }^{3}$ Department of Medicine, Karolinska Institute, and the Research Centre at Huddinge Hospital, Sweden
}

\begin{abstract}
Summary. The insulin-like growth factor I receptor and the activity of its associated tyrosine kinase activity were characterised in wheat germ agglutinin extracts from skeletal muscle biopsies from nine control and ten obese Type 2 (non-insulindependent) diabetic subjects, who had marked peripheral in vivo insulin resistance for glucose disposal and hyperinsulinaemia. In parallel studies, the concentration of the insulin receptor and its tyrosine kinase activity were examined in the biopsy extracts and compared to the findings for the insulinlike growth factor I receptor system. Specific binding sites for insulin-like growth factor I were detected. The receptor binding of insulin-like growth factor I was not changed in the obese diabetic subjects as compared to binding activity in the biopsies from the control subjects. The molecular weight of the insulin-like growth factor I receptor alpha subunit was similar in both groups $(135 \mathrm{kDa})$. The insulin-like growth factor I stimulated tyrosine kinase activity was also similar for the
\end{abstract}

two groups. In contrast, insulin binding activity was $30 \%$ less in the receptor extracts from the in vivo insulin resistant group when compared to the control group. Moreover, insulinstimulated tyrosine kinase activity was reduced in the former group by $40 \%$ when the value was corrected for insulin binding. Thus, specific insulin-like growth factor I receptors are present in human skeletal muscle. These receptors are normal in insulin resistant obese Type 2 diabetic subjects. The findings argue that alterations in the insulin receptor number and tyrosine kinase activity of muscle, which may underlie the marked insulin resistance found in obese Type 2 diabetic patients for glucose disposal, are quite specific for the insulin receptor, since the closely related insulin-like growth factor I receptor was not affected in these patients.

Key words: Somatomedin, insulin, tyrosine kinase, diabetes mellitus.
Insulin-like growth factor I (IGF-I) action is associated with growth promotion and the production of insulinlike effects in a number of tissues [1,2]. The receptor for IGF-I mediates part or all of these effects, depending on the tissue and the extent of cross-reaction of the hormone with the insulin receptor. This cross reaction arises from the similarity between IGF-I and proinsulin and from the highly homologous structural identity that exists between the two receptor systems [1-3]. For example, selected areas in the deduced amino acid sequences for the two receptors for the putative hormone binding regions and for the tyrosine kinase catalytic sites range from $48 \%$ to $84 \%$ identity [3]. Because of this high homology, regulatory processes that control receptor number or that modulate tyrosine kinase activity may act on both receptors. This concept is supported by studies of muscle from obese mice that demonstrate resistance to both IGF-I and insulin as measured by the activation of glucose transport and the stimulation of glycogen synthase [4]. Other studies conducted in tissue culture have also demonstrated examples of parallel regulation of both receptor systems [5], as well as instances in which the two systems are not regulated in tandem [6]. The IGF-I receptor in human muscle has not been studied so far. Such studies are of importance for the understanding of normal physiology, as well as of insulin resistance and glucose intolerance, since skeletal muscle plays a major role in glucose disposal.

Recent work from our laboratory [7] and from the laboratories of others [8-11] have shown an alteration in the tyrosine kinase activity of the insulin receptor in the insulin target tissues from patients with most common forms of insulin resistance, i.e. obesity with or without Type 2 (non-insulin dependent) diabetes mellitus. In skeletal muscle from these subjects, the degree of the reduction in insulin-stimulated kinase activity corrected for insulin binding can reach $40 \%[7,9]$. Therefore, since skeletal muscle also contains the IGF-I receptor [4], an alteration in the tyrosine kinase activity of this receptor would be expected in common insulin resistant states if 
parallel regulation with the insulin receptor occurs. This possibility was examined by the present study in which IGF-I binding activity, and IGF-I stimulated tyrosine kinase activity were measured in receptor extracts from skeletal muscle biopsies of control subjects and obese Type 2 diabetic subjects (where marked insulin resistance was expected). Furthermore, it is not known if the IGF-I receptor is present in any of the human target tissues for insulin. So far, only the liver and the adipose tissue has been investigated in this respect; no IGF-I receptors were found in adult human fat and liver cells $[12,13]$. Parallel studies of the insulin receptor in the same muscle extracts were conducted as well, and the results compared to the findings from the IGF-I investigations.

\section{Subjects and methods}

\section{Materials}

Human recombinant IGF-I was supplied by Kabi-Vitrum Co., (Stockholm, Sweden) and porcine insulin by Eli Lilly Co., (Indianapolis, Ind, USA). Mono-iodinated (A-14) ${ }^{125}$ I-insulin, ${ }^{125} \mathrm{I}$-IGF-I, and D$3\left({ }^{3} \mathrm{H}\right)$-glucose were purchased from Amersham (London, UK). The monoclonal antibody, alpha-IR ${ }_{3}$, was kindly supplied by $\mathrm{Dr}$. S. Jacobs (Burroughs Wellcome, Research Triangle Park, NC, USA). Semisynthetic regular human insulin for the euglycaemic insulin infusion studies was provided by Novo (Copenhagen, Denmark). The sources of the other reagents have been reported previously $[8,14]$.

\section{Human subjects}

All of the subjects were 60 -year-old men who participated in a health screening study in Uppsala, a middle-sized Swedish town [15]. The subjects were healthy and drug-free except for the presence of obese Type 2 diabetes in 10 of the 19 individuals. This condition, which was diagnosed during the health screening procedures, was not treated prior to the investigation. According to dietary histories [15], all subjects consumed a similar diet that consisted of $15 \%$ protein, $50 \%$ carbohydrate, and $35 \%$ fat with an intake of 10.5 megajoule $/ 24 \mathrm{~h}$.

Following an overnight fast, plasma levels for glucose and insulin were determined as previously described [15]. Serum levels for total IGF-I were kindly measured by the Clinical Research Center, Rochester, NY, USA, using a radioimmunoassay kit (Incstar Corporation, Stillwater, Minn, USA). The measures were performed exactly as described by the manufacturer. Also, an intravenous glucose tolerance test was conducted and body mass index measured [15]. On separate days after an overnight fast, either an euglycaemic insulin clamp was performed (see below) or three biopsies (100 mg-250 g total weight) were taken from the left vastus lateralis muscle and immediately frozen in liquid $\mathrm{N}_{2}$.

The study was approved by the Ethics Committee of Uppsala University. The experimental procedures were explained in detail to each participant and informed consent was obtained.

\section{Glucose clamp technique}

The in vivo response of the subjects to insulin was measured by the eu glycaemic clamp technique as described in detail by DeFronzo et al. [16]. Arterialised venous blood ( $\mathrm{PA} \mathrm{O}_{2}>85 \mathrm{~mm} \mathrm{Hg}$ ) was used for measurements of plasma glucose levels [17]. Insulin was infused as an initial priming dose for the first $10 \mathrm{~min}$ and then as a continuous infusion for $110 \mathrm{~min}$ at a rate of $56 \mathrm{mU} / \mathrm{m}^{2} / \mathrm{min}$ in all subjects. This rate of infusion resulted in a mean plasma insulin concentration of $113 \mathrm{mU} / \mathrm{l}$ (range of 71-145 mU/1). Plasma glucose concentration was measured every $5 \mathrm{~min}$ with a glucose analyzer Ii (Beckman Instruments, Fullerton, Calif, USA). The target plasma glucose concentration during the clamp procedure was $5.3 \mathrm{mmol} / 1$, which was reached within $60 \mathrm{~min}$ of the start of insulin infusion. In two control and two diabetic subjects, endogenous glucose production was measured during the glucose clamp procedure using D-3- $\left({ }^{3} \mathrm{H}\right)$ glucose. Diabetic subjects received a priming dose of $40 \mu \mathrm{Ci}$ and normal individuals a dose of $20 \mu \mathrm{Ci}$ in a $20 \mathrm{ml}$ intravenous bolus. Continuous infusions of radiolabelled glucose of $0.4 \mu \mathrm{Ci} / \mathrm{min}$ and $0.2 \mu \mathrm{Ci} / \mathrm{min}$ were carried out for $180 \mathrm{~min}$ and $120 \mathrm{~min}$ respectively, for the diabetic and control subjects before the start of the insulin infusions. Plasma samples were taken every 5 min during the last $30 \mathrm{~min}$ of this period to determine the specific radioactivity of the glucose pool as previously described [18].

Steady-state plasma glucose and insulin concentrations were determined and the $\mathrm{M}$ value (rate of glucose infusion) was calculated [19]. The rate of endogenous glucose production was calculated as described previously [19].

\section{Extraction of receptors for insulin and IGF-I}

The muscle biopsies were stored in liquid $\mathrm{N}_{2}$ and all subsequent steps in receptor isolation were carried out at $4^{\circ} \mathrm{C}$. The receptors were extracted as described [7]. The extract was placed on a column of wheat germ agglutinin (WGH) coupled to agarose [14]. The extract was cycled over the column and washed as described [8]. Following centrifugation of the columns to remove the wash buffer from the column bed [8], a $0.3 \mathrm{~mol} / 1 \mathrm{n}$-acetylglucosamine solution that contained $50 \mathrm{mmol} / 1$ HEPES, $\mathrm{pH} 7.4$ and $0.1 \%$ Triton $\mathrm{X}-100$ was added to the capped column and mixed with the WGA-agarose. After an incubation period of $1 \mathrm{~h}$ at $4^{\circ} \mathrm{C}$, the column was uncapped and the eluate collected by centrifugation. The eluate was divided into equal samples that were used for hormone binding studies and studies of the tyrosine kinase activities of the insulin and IGF-I receptors. Protein content of the samples was determined by the Bio-Rad method. It varied between 12.5 to $32.5 \mathrm{ng}$ per $\mu \mathrm{l}$ of WGA extract. Recoveries of the receptors for IGF-I and insulin as measured by hormone binding assays were, respectively, $76 \%$ and $95 \%$.

\section{Hormone binding studies}

The specific binding of ${ }^{125} \mathrm{I}$ (A-14) insulin and ${ }^{125} \mathrm{I}-\mathrm{IGF}-\mathrm{I}$ was determined in duplicate by a microassay method described previously [7]. In brief, WGA extract was incubated in the presence or absence of native hormone and $50 \mathrm{pmol} / 1$ of the radiolabelled ligand. Non-specific binding of ${ }^{125} \mathrm{I}$-IGF-I as determined with $1 \mu \mathrm{mol} / 1$ unlabelled IGF-I was approximately $20 \%$ of total tracer binding compared to non-specific binding of $10 \%$ for ${ }^{125} \mathrm{I}$-insulin. Degradation of radiolabelled IGF-I or insulin was less than $5 \%$ of the tracer added to the assay. Hormone binding activity was linearly related to the amount of WGA extract added to the assay. The intraassay coefficient of variance for insulin and IGF-I binding of tracer hormone was $9 \%$.

\section{Tyrosine kinase assay}

The tyrosine kinase assay is a modification of a previous assay [7]. The assay was modified by the step that allowed the receptors to undergo autophosphorylation before the exogenous substrate was added. This step prevents the substrate from inhibiting receptor autophosphorylation that would in turn inhibit the full activation of the kinase activity [20]. The assay was conducted following a $3 \mathrm{~h}$ incubation at $4^{\circ} \mathrm{C}$ of the 
Table 1. Clinical data for the human subjects

\begin{tabular}{llllllc}
\hline & $\begin{array}{l}\text { Number } \\
\text { of subjects }\end{array}$ & $\begin{array}{l}\text { Age } \\
\text { (years) }\end{array}$ & $\begin{array}{l}\text { Body mass } \\
\text { index } \\
\left(\mathrm{kg} / \mathrm{m}^{2}\right)\end{array}$ & $\begin{array}{l}\text { Intravenous } \\
\text { glucose tolerance } \\
(\% \text { per min) }\end{array}$ & $\begin{array}{l}\text { Plasma } \\
\text { glucose } \\
(\mathrm{mmol} / \mathrm{l})\end{array}$ & $\begin{array}{l}\text { Plasma } \\
\text { insulin } \\
(\mathrm{mU} / \mathrm{l})\end{array}$ \\
\hline $\begin{array}{l}\text { Non-obese control } \\
\text { subjects }\end{array}$ & 9 & $62 \pm 1$ & $26.0 \pm 0.7$ & $1.34 \pm 0.16$ & $4.7 \pm 0.2$ & $\begin{array}{l}\text { Serum } \\
\text { IGF-I } \\
(\mathrm{nmol} / \mathrm{l})\end{array}$ \\
$\begin{array}{l}\text { Obese Type 2 } \\
\text { (non-insulin-dependent) } \\
\text { diabetic patients }\end{array}$ & 10 & $63 \pm 1$ & $34.8 \pm 1.1$ & $0.45 \pm 0.03$ & $9.7 \pm 1.0$ & $29.7 \pm 5.7$ \\
$p$
\end{tabular}

Table 2. Glucose clamp studies ${ }^{\mathrm{a}}$

\begin{tabular}{lccl}
\hline & Control subjects & $\begin{array}{c}\text { Obese Type 2 } \\
\text { diabetic subjects }\end{array}$ & $p$ \\
\hline $\begin{array}{l}\text { Plasma glucose, } \\
\mathrm{mmol} / 1\end{array}$ & $5.3 \pm 0.02$ & $5.4 \pm 0.06$ & $\mathrm{NS}$ \\
$\begin{array}{c}\text { Plasma insulin, } \\
\quad \mathrm{U} / \mathrm{ml}\end{array}$ & $101 \pm 7$ & $125 \pm 5$ & 0.02 \\
$\begin{array}{c}\mathrm{M} \text { values (mg glucose } \\
\left.\quad \mathrm{kg}^{-1} \cdot \mathrm{min}^{-1}\right)\end{array}$ & $6.33 \pm 0.6$ & $2.8 \pm 0.3$ & 0.001 \\
$\mathrm{M} / \mathrm{I} \times 100$ & $6.7 \pm 0.9$ & $2.2 \pm 0.4$ & 0.001 \\
\hline
\end{tabular}

${ }^{\text {a }}$ Insulin infusion rate of $56 \mathrm{mU} / \mathrm{m}^{2} / \mathrm{min}$

receptor ( $20 \mu \mathrm{l}$ of the WGA extract) with the indicated concentration of hormone in a total volume of $30 \mu \mathrm{l}$. Next, $10 \mu \mathrm{l}$ of a mixture of $200 \mu \mathrm{mol} / 1 \mathrm{ATP}, 40 \mathrm{mmol} / 1 \mathrm{MgCl}_{2}, 8 \mathrm{mmol} / 1 \mathrm{MnCl}_{2}$, and $8 \mathrm{mmol} / 1$ p-nitrophenylphosphate was added and the incubation continued for $5 \mathrm{~min}$ at $24^{\circ} \mathrm{C}$ to allow autophosphorylation of the receptor before the addition of the substrate and radiolabelled ATP. A $10 \mu \mathrm{l}$ amount of the artifical substrate, $\mathrm{Glu}_{80} \mathrm{Tyr}_{20},(5 \mathrm{mg} / \mathrm{ml})$ mixed with $5 \mu \mathrm{Ci}$ of (gamma- ${ }^{32} \mathrm{P}$ ) ATP was added to start the substrate reaction. The assay, which was run in duplicate, was terminated after $20 \mathrm{~min}$ at $24^{\circ} \mathrm{C}$ and the amount of phosphate incorporated into $\mathrm{Glu}_{80} \mathrm{Tyr}_{20}$ was measured as previously described [7].

IGF-I and insulin-stimulated phosphorylation of Glu $80 \mathrm{Tyr}_{20}$ was linear with respect to time and to the amount of hormone receptors added. The hormone stimulated activity was dependent on the presence of the Glu ${ }_{80} \mathrm{Tyr}_{20}$; in its absence, IGF-I stimulation of protein phosphorylation was completely absent, and insulin stimulation was only $11 \%$ of the amount found in the presence of the artifical substrate. The intraassay coefficient of variation for the tyrosine kinase activity measurements was $5 \%$. Since the relationship between receptor content and total protein concent in the WGA extract was unknown, all tyrosine kinase data were normalised for binding activity at tracer concentration for IGF-I or insulin.

\section{Cross-linking studies of the IGF-I receptor}

Pooled muscle biopsies from three normal subjects and three obesediabetic subjects were extracted and partially purified on WGA-agarose as described above. The column eluate from each group was divided into three equal parts. ${ }^{125} \mathrm{I}$-IGF-I $(0.5 \mathrm{nmol} / \mathrm{l})$ was added to each fraction in the presence or absence of $1 \mu \mathrm{mol} / 1$ native IGF-I or $100 \mu \mathrm{mol} / 1$ insulin. After an overnight incubation at $4^{\circ} \mathrm{C}$, the hormone receptor complex was precipitated by the polyethylene glycol method. The pellet was washed once with $10 \%$ polyethylene glycol and resuspended in $300 \mu \mathrm{l}$ of a $50 \mathrm{mmol} / 1$ HEPES buffer, $\mathrm{pH} 7.4$, that contained $0.05 \%$ Triton X-100. Disuccidimidyl suberate $(0.5 \mathrm{mmol} / 1)$ was added to the suspended complex; after $1 \mathrm{~h}$ at $4^{\circ} \mathrm{C}$, the reaction was terminated by the addition of $20 \mathrm{mmol} / \mathrm{I}$ Tris-HCI, $\mathrm{pH} 7.4$ [14]. The reaction mixture was precipitated by the polyethylene glycol method and subjected to PAGE-SDS ( $7.5 \%$ acrylamide) and autoradiography as previously described [14].

\section{Statistical analysis}

The statistical significance of the results was analysed by Student's unpaired t-test. The values are the mean \pm SEM. The coefficient of variance for the different assays was calculated from the results of duplicated determinations in the whole material ( 29 subjects).

\section{Results}

\section{Patient characteristics}

Table 1 summarises the characteristics of the control individuals and the obese Type 2 diabetic subjects. The obese Type 2 diabetic group had clearly elevated fasting glucose and insulin levels, as well as, abnormal intravenous glucose tolerance. This indicates overall insulin resistance. The levels of IGF-I were almost doubled in the diabetic group ( $p<0.025$ ).

Table 2 shows the results of the glucose clamp studies carried out with the control and diabetic subjects. Insulin resistance was demonstrated in the diabetic subjects by a greater than $50 \%$ decrease in the $M$ value which occurred even though the steady-state insulin levels were higher than the levels present in the control group.

It was observed that $90 \%$ or greater suppression of basal endogenous glucose production was achieved by the infusion of insulin in two control and two diabetic subjects. Thus, the decrease in the $M$ values for the obese diabetic patients was not the result of a failure of suppression of hepatic glucose production. Instead, it reflects the degree of insulin resistance in peripheral tissues.

\section{Biochemical studies}

High affinity specific IGF-I binding was detected in the extracts as illustrated by a $50 \%$ inhibition of tracer hormone binding by $0.3 \mathrm{nmol} / 1$ native IGF-I, whereas native insulin was much less effective (Fig.1). Insulin binding demonstrated the properties expected of the insulin receptor. Also, the monoclonal antibody against

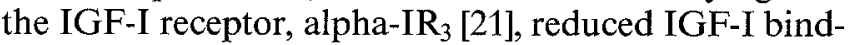
ing to $46 \pm 5 \%$ of control $(100 \%)$ in comparison to insulin binding, which was not altered by the antibody. 


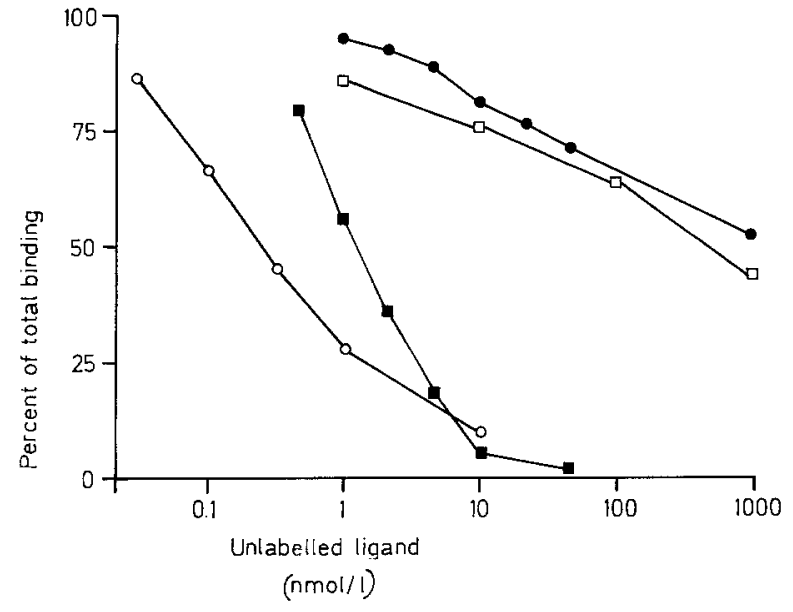

Fig. 1. IGF-I and insulin binding to the receptor preparation from human skeletal muscle. ${ }^{125} \mathrm{I}$-IGF-I or ${ }^{125} \mathrm{I}$-insulin were incubated with the indicated concentration of unlabelled IGF-I or insulin. In these studies, the $\mathrm{B} / \mathrm{F}$ values obtained with tracer concentrations of the labelled hormones were approximately 0.06 for IGF-I and 0.1 for insulin per $0.5 \mu \mathrm{g}$ protein. The ability of unlabelled IGF-I to inhibit labelled IGF-I is indicated with $O$ and to inhibit labelled insulin with $\square$; the ability of unlabelled insulin to inhibit tracer IGF-I is symbolised by and to inhibit tracer insulin by

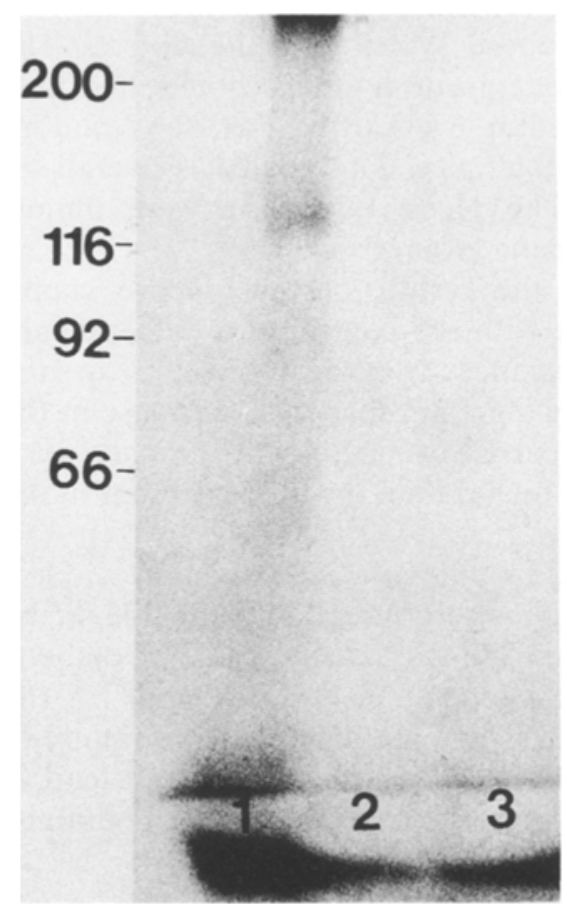

Fig. 2. Affinity labelling of the IGF-I binding site. Affinity labelling is shown in the absence of any unlabelled hormone (Lane 1), in the presence of $1 \mu \mathrm{mol} / 1$ IGF-I (Lane 2), and in the presence of $100 \mu \mathrm{mol} / 1$ insulin (Lane 3). The position of the molecular weight markers are indicated at the left of the autoradiogram

Affinity labelling studies with ${ }^{125}$ I-IGF-I show that the material specifically labelled had a molecular weight of $135 \mathrm{kDa}$ (Fig. 2). This was appropriate for the IGF-I receptor alpha subunit [22]. There was also labelling of very large molecular weight material near the top of the gel that was not resolved by gel electrophoresis. It
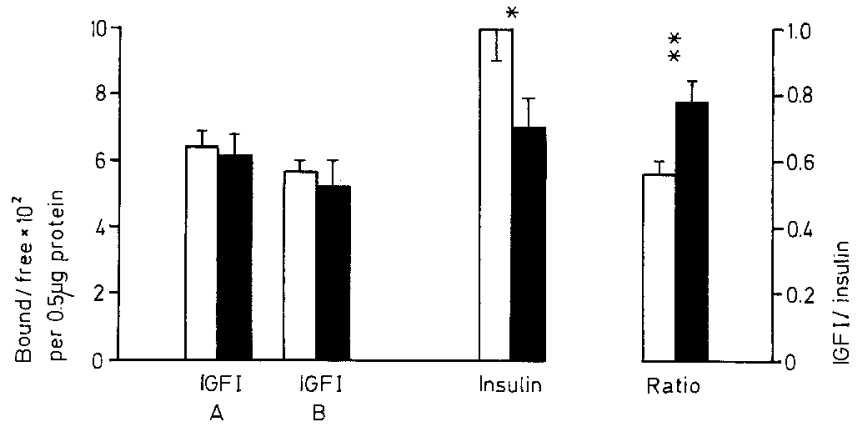

Fig. 3. IGF-I and insulin binding to the muscle extracts from obese Type 2 diabetic subjects ( $\square$ ) and normal control subjects ( $\square$ ). A: Tracer IGF-I binding in which the non-specific component was measured with $1 \mu \mathrm{mol} / 1$ IGF-I. B: IGF-I binding measured with $100 \mu \mathrm{mol} / 1$ insulin to determine non-specific binding activity. Insulin: Tracer insulin binding by the WGA extracts from normal and diabetic subjects: Ratio: The IGF-I/insulin binding ratio for the two groups. The results are the mean \pm SEM for 8 normal and 9 obese diabetic subjects. $*=p<0.05 ; * *=p<0.01 . \perp=\square ; T=$

is not likely that the latter band contained the beta subunit of the receptor, since the latter unit usually is not detected by this labelling technique. Instead, the material probably respresents artefacts such as cross-linked aggregates of the IGF-I receptor, since both $1 \mu \mathrm{mol} / 1$ IGF-I and $100 \mu \mathrm{mol} / 1$ insulin completely inhibited ${ }^{125} \mathrm{I}-$ IGF-I affinity labelling. Moreover, there was no evidence of ${ }^{125}$ I-IGF-I labelling of either an IGF-I serum binding protein or the IGF-II receptor. In these studies, $100 \mu \mathrm{mol} / 1$ insulin was an effective inhibitor of IGF-I labelling, thus indicating that serum binding protein or the IGF-II receptor were not involved in the binding of tracer IGF-I [1]. Essentially the same results were found with muscle extracts from obese diabetic subjects (data not shown).

The ability of $100 \mu \mathrm{mol} / \mathrm{l}$ insulin to discriminate the IGF-I receptor from the IGF-II receptor was used throughout the ${ }^{125} \mathrm{I}-\mathrm{IGF}-\mathrm{I}$ binding studies. The difference between the amounts of ${ }^{125}$ I-IGF-I displaced by $1 \mu \mathrm{mol} / 1 \mathrm{IGF}-\mathrm{I}$ and $100 \mu \mathrm{mol} / 1$ insulin amounted to $13-15 \%$, i.e. $100 \mu \mathrm{mol} / 1$ insulin was about $85 \%$ as effective as $1 \mu \mathrm{mol} / 1$ IGF-I in inhibiting tracer IGF-I binding. As shown in Figure 3, this difference was the same for control and diabetic subjects. Therefore, the IGF-I binding activity was contributed to primarily by the type I IGF receptor, and the small amount of IGF-I binding to the type II receptor or serum binding proteins, which may be present in the samples did not differ from normal in the obese diabetic group.

Figures 3 and 4 illustrate the lack of change in the specific binding if IGF-I to the IGF-I receptor in the obese diabetic subjects. The displacement curve with native IGF-I was basically the same for the two groups. In addition, the $\mathrm{B} / \mathrm{F}$ values for tracer ${ }^{125} \mathrm{I}$-IGF-I were not different for the two groups. This observation is in contrast to the findings with the insulin receptor. As shown in Figure 3, trace insulin binding by the obese diabetic group was significantly lower by $30 \%$ when compared to the binding activity of the control group. 
The tyrosine kinase activity of the IGF-I receptor and the insulin receptor were measured and compared between the two groups (Fig. 5). Basal phosphate incorporation (absence of hormone) was not different per $\mu \mathrm{g}$ of protein between the two groups, i.e. $2.4 \pm 0.2 \mathrm{pmol}$ phosphate incorporated per $\mu \mathrm{g}$ protein per $20 \mathrm{~min}$ for the control group versus $2.3 \pm 0.3$ for the obese diabetic group. More importantly, there was no difference between the two groups for IGF-I stimulation of tyrosine kinase activity in the WGA extracts. IGF-I generated similar amounts of phosphorylated substrate by receptor preparations from both groups when expressed per IGF-I binding activity as shown or per $\mu \mathrm{g}$ of protein in the WGA extract. It should be noted that the kinase activity stimulated by IGF-I resulted in the phosphorylation of tyrosines since no stimulation was observed in the absence of the substrate, $\mathrm{Glu}_{80} \mathrm{Tyr}_{20}$. A comparision of the kinase activities for the two receptor systems showed that the insulin receptor was much more active than the IGF-I receptor. Although the muscle extracts from the obese diabetic group had a normal response to IGF-I, they lacked a normal response to insulin (Fig. 5). These studies, which were carried out in the same preparations and in parallel with the IGF-I studies, clearly showed a decrease in the kinase activity of the insulin receptor for both concentrations of insulin used. Because of this decrease in insulin receptor kinase activity, the IGF-I - insulin ratio for kinase stimulation - was altered in the Type 2 diabetic obese subjects. Thus, there was proportionally more IGF-I stimulation of tyrosine kinase activity in the diabetic preparations than in the control group.

\section{Discussion}

The similarities between the receptors for IGF-I and insulin [1-3] and their coupled regulation under certain conditions [4] prompted us to examine the IGF-I receptor in skeletal muscle from normal subjects and obese Type 2 diabetic subjects who are insulin resistant and have alterations in the insulin receptor in target tissues [7-11]. To the best of our knowledge, the human muscle IGF-I receptor has not been characterised previously. The initial studies characterised the IGF-I binding activity of the muscle extracts to validate that the IGF-I receptor was being studied and not the IGF-II receptor or IGF-I serum binding proteins.

The results from the affinity cross-linking experiments with ${ }^{125}$ I-IGF-I and the ${ }^{125}$ I-IGF-I binding studies strongly argues that the IGF-I receptor contributes to the binding activity in the extracts from the muscle biopsies. This is in contrast to human fat and liver cells - the other two major insulin target cells which do not seem to contain IGF-I receptors [12, 13]. However, the data do not completely exclude some contribution by the IGF-II receptor or the serum binding proteins to the binding of IGF-I. The $10-15 \%$ of

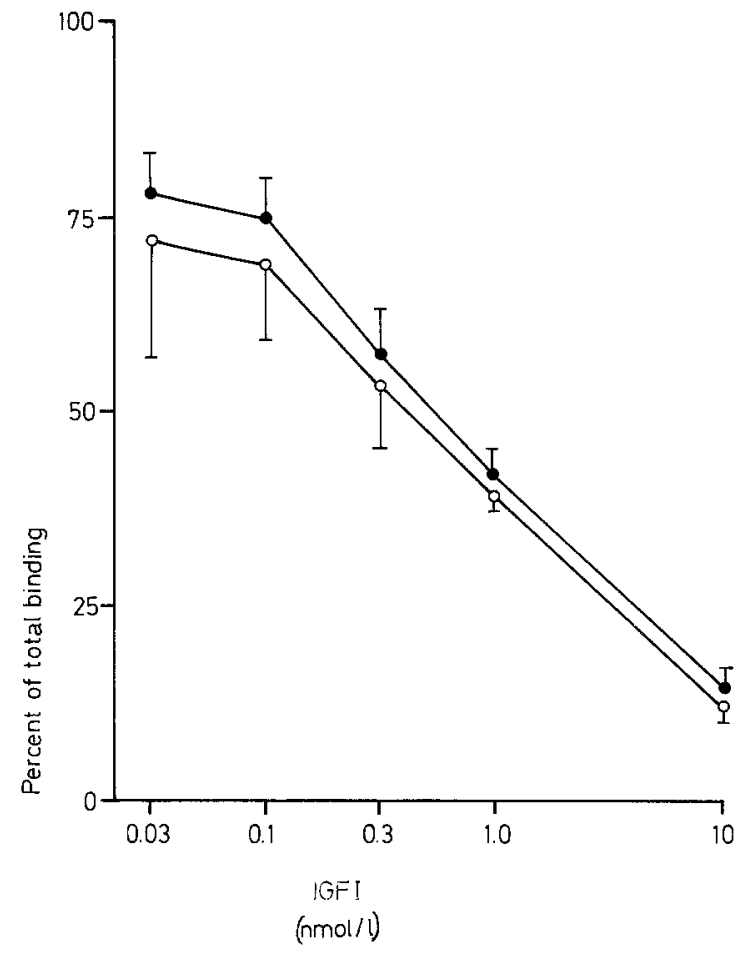

Fig.4. IGF-I competition curves for normal $O$ ) and obese Type 2 diabetic subjects ( $)$. The results are then mean \pm SEM for the subjects studied in Figure 3. $T=\square ; \perp=\square$

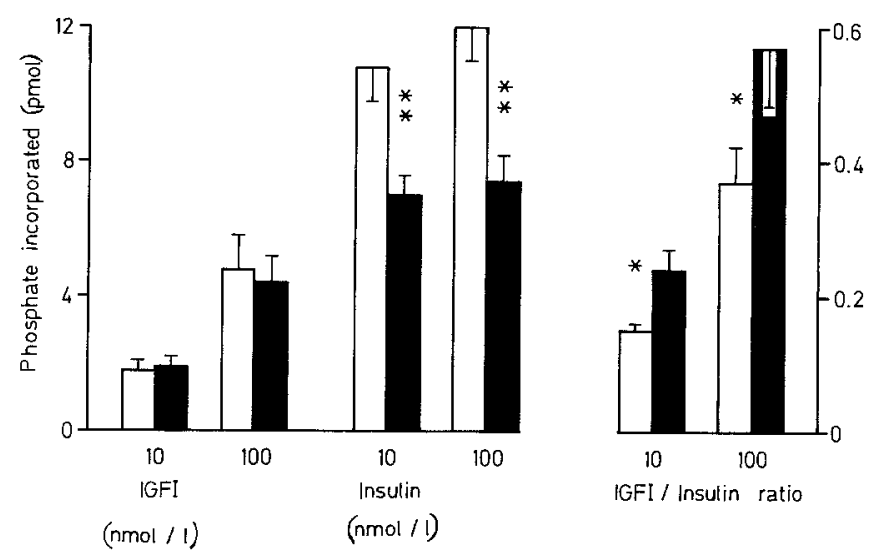

Fig.5. Tyrosine kinase activity of the IGF-I and insulin receptors for normal ( $\square$ ) and obese Type 2 diabetic $(\square)$ subjects. The hormone concentration used to stimulate the tyrosine kinase activity is indicated under the bar. The ratio of IGF-I/insulin stimulation for the two hormone concentrations is shown in the right panel. The amount of phosphate incorporated was calculated and expressed per fmol of IGF-I or insulin binding activity at tracer concentrations of each hormone. The results are the mean \pm SEM of 7 control subjects and 8 obese diabetic subjects. $*=p<0.05 ; * *=p<0.005$ and indicates SEM. $T=\square ; L=$

tracer IGF-I binding that was not inhibited by $100 \mu \mathrm{mol} / 1$ insulin may be a result of the binding by these other structures.

As reported, there was no difference in IGF-I binding between obese Type 2 diabetic and control subjects, although obese Type 2 diabetic patients had marked peripheral insulin resistance as evidenced by the glucose clamp studies. This similarity in binding extended to the 
competition curves for the receptor extracts from both study groups. Therefore, since the IGF-I competition curves and the amount of tracer IGF-I binding were similar for the two groups, the presence of obesity and Type 2 diabetes did not change the hormone binding characteristics and the concentration of the skeletal muscle IGF-I receptor. Increased total serum levels of IGF-I were recorded in the diabetic patients. Usually high hormone levels are associated with receptor down regulation. However, the somatomedins (unlike other peptide hormones) circulate bound to carrier proteins [2]. This fraction, which constitutes most of the circulating IGF-I, may not interact with the receptor. In a previous study on [23] longterm treated Type 2 diabetic patients, decreased serum levels of IGF-I were observed. The difference in results may be due to the fact that we investigated newly diagnosed and untreated patients.

The same tissue extract used to study the IGF-I receptor was also used in the measurement of insulin binding activity. These studies showed a significant decrease of $30 \%$ in tracer insulin binding by the extracts from the diabetic patients. This difference was not detected in a previous study of insulin binding in Type 2 diabetes [7], probably because the degree of fasting hyperinsulinaemia in the previously examined subjects was much less than that found in the present study, i.e. 3 -fold the mean control value in the previous study versus 6 -fold the control value in the present work. Since down-regulation of the insulin receptor has been closely associated with hyperinsulinaemia, the loss of insulin binding activity should be magnified in the present group of diabetic subjects.

The studies of the tyrosine kinase activity provided information on a second feature of the IGF-I receptor, i.e. its ability to phosphorylate proteins on tyrosine residues [1, 22]. In the presence of $10 \mathrm{nmol} / 1 \mathrm{IGF}-\mathrm{I}$, this activity, however, was much less (e.g. about $15 \%$ ) than the comparable activity found with $10 \mathrm{nmol} / 1$ insulin stimulation of the insulin receptor. With this hormone concentration, there is little cross-binding of ligands by the two types of receptors [1]. Thus, the difference in the kinase activity between the two receptors may stem from differences in substrate preference or in the conditions of the assay. Alternatively, the tyrosine kinase activity of the IGF-I receptor is less active than the kinase actvity of the insulin receptor.

The IGF-I stimulated kinase activity was essentially the same in the receptor extracts from obese diabetic and control muscles. In this respect, it should be noted that normal tyrosine kinase activity of the IGF-I receptor in erythrocytes has been demonstrated in Type 2 diabetes [24].

The results with the IGF-I receptor kinase activity in Type 2 diabetes are clearly different from the findings with the kinase activity of the insulin receptor. Thus, in the same receptor preparations used in the IGF-I studies and analysed at the same time, we found a marked reduction in the insulin stimulated tyrosine ki- nase in muscle extracts from the diabetic subjects. The results of the kinase studies of the insulin receptor in obese Type 2 diabetic patients also agree with previous findings by us [7] and others [8-11, 24] that document comparable reductions in its activity. Also, the results further support the conclusion drawn from the hormone binding studies, that the alterations found in the obese Type 2 diabetes syndrome involve only the insulin receptor and not the receptor for IGF-I. The different results obtained with receptor kinase activity for IGF-I and insulin in the latter condition cannot be explained by receptor cross reactions. If so, both tyrosine kinases should be affected by the obese diabetes state.

In summary, the present studies show that a biologically active IGF-I receptor is present in human skeletal muscle. This receptor is not affected by the processes that induces alterations in the insulin receptor of muscle in insulin resistant obese Type 2 diabetic patients. Whether the latter is true for non-obese Type 2 diabetic patients or non-diabetic obese subjects remains to be established. However, it is possible to consider that the two receptor systems are regulated by separate processes, at least in human muscle.

Acknowledgements. This study was supported by the Swedish Medical Research Council (Grants 1034 and 5446), The Swedish Diabetes Association, The Foundation of Nordic Insulin, Folksam and ThroneHolst, and NIH grant AM 20129.

\section{References}

1. Rechler MM, Nissley SP (1985) The nature and regulation of the receptors for insulin-like growth factors. Ann Rev Physiol 47: $425-442$

2. Froesch ER, Schmid C, Schwander J, Zapf J (1985) Actions of insulin-like growth factors. Ann Rev Physiol 47: 443-467

3. Ullrich A, Gray A, Tam AW, Yang-Feng T, Tsubokawa M, Collins C, Henzel W, Le Bon T, Kathuria S, Chen E, Jakobs S, Francke U, Ramachandran J, Fujita-Yamaguchi Y (1986) Insulin-like growth factor I receptor structure: comparision with insulin receptor suggests structural determinants that define functional specificity. EMBOJ 5: 2503-2512

4. Poggi C, Marchand-Brustel YL, Zapf J, Froesch ER, Freychet P (1979) Effects and binding of insulin-like growth factor $I$ in the isolated soelus muscle of lean and obese mice: comparison with insulin. Endocrinology 105: 723-730

5. Knight AB, Rechler MM, Romanus JA, Van Obberghen-Schilling EE, Nissley SP (1981) Stimulation of glucose incorporation and amino acid transport by insulin and insulin-like growth factor in fibroblasts with defective insulin receptors cultured from a patient with leprechaunism. Proc Natl Acad Sci USA 78: 2554-2558

6. Heaton JH, Krett NL, Alvarez JM, Gelehrter TD, Romanus JA, Rechler MM (1984) Insulin regulation of insulin-like growth factor action in rat hepatoma cells. J Biol Chem 259:2396-2402

7. Arner P, Pollare T, Lithell H, Livingston JN (1987) Defective insulin receptor tyrosine kinase in human skeletal muscle in obesity in Type 2 (non-insulin-dependent) diabetes mellitus. Diabetologia 30: $437-440$

8. Freidenberg GR, Henry RR, Klein HH, Reichard DR, Olefsky JM (1987) Decreased kinase activity of insulin receptors from adipocytes of non-insulin dependent diabetic subjects. J Clin Invest 79: 240-250

9. Caro J, Ittoop O, Pories WJ, Meelham D, Flickinger EG, Thomas F, Jenguin M, Silverman JF, Khazanie PG, Sinha MK (1986) 
Studies of the mechanisms of insulin resistance in the liver from humans with non-insulin dependent diabetes. J Clin Invest 78 : 249-258

10. Sinha MK, Pories WJ, Flickinger EG, Meelheim D, Caro JF (1987) Insulin receptor kinase activity of adipose tissue from morbidly obese humans with and without non-insulin dependent diabetes. Diabetes 36: 620-625

11. Caro JF, Sinha MK, Raju SM, Ittoop O, Pories WJ, Flickinger EG, Meelheim D, Dohm GL (1987). Insulin receptor kinase in human skeletal muscle from obese subjects with and without noninsulin dependent diabetes. J Clin Invest 79: 1330-1337

12. Bolinder J, Lindblad A, Engfeldt P, Arner P (1987) Studies of acute effects of insulin-like growth factors I and II in human fat cells. J Clin Endocrinol Metab 65: 732-737

13. Caro JF, Poulos J, Ittoop O, Pories WJ, Flickinger EG, Sinha MK (1988) Insulin-like growth factor-I binding in hepatocytes from human liver, human hepatoma, and normal, regenerating and fetal rat liver. J Clin Invest 81: 976-981

14. Arenis G, Livingston JN (1986) Alterations in the tyrosine kinase activity of the insulin receptor produced by in vitro hyperinsulinemia. J Biol Chem 261: 147-153

15. Bolinder J, Lithell H, Skarfors E, Arner P (1986) Effects of obesity, hyperinsulinemia, and glucose intolerance on insulin action in adipose tissue of sixty-year-old men. Diabetes 35: 282 290

16. DeFronzo RA, Robin JD, Andres R (1979) Glucose clamp technique: a method for quantifying insulin secretion and resistance. Am J Physiol 237: 214-233

17. McGuire EAM, Helderman JHG, Tobin JD, Andres R, Berman M (1976) Effects of arterial versus venous sampling. An analysis of glucose kinetics in man. J Appl Physiol 41: 565-573

18. Altszuler N, Barkai A, Bjerknes C, Gottlieb B, Steele R (1975) Glucose turnover values in the dog obtained with various species of radiolabeled glucose. Am J Physiol 229: 1662-1667
19. Bergman RN, Finegood DT, Ader M (1985) Assessment of insulin sensitivity in vivo. Endocr Rev 6:45-86

20. Shoelson SE, Shite MF (1987) The insulin receptor: relationship between sites of autophosphorylation and kinase activity. Diabetes 36 [Suppl 1]: 54A

21. Kull FC, Jacobs S, Su Y-F, Svoboda ME, Van Wyk JJ, Cuatrecasas $\mathrm{P}$ (1983) Monoclonal antibodies to receptors for insulin and somatomedin-C. J Biol Chem 258: 6561-6566

22. Le Bon T, Jacobs S, Cuatrecasas P, Kathuria S, Fujita-Yamaguchi $Y$ (1986) Purification of insulin-like growth factor I receptor from human placental membranes. J Biol Chem 261: 7685-7689

23. Tan K, Baxter RC (1986) Serum insulin-like growth factor I levels in adult diabetic patients: the effect of age. $\mathbf{J}$ Clin Endocrinol Metab 63: 651-655

24. Comi R, Grunberger G, Gorden P (1987) Relationship of insulin binding and insulin-stimulated tyrosine kinase activity is altered in Type II diabetes. J Clin Invest 79: 453-462

25. Truglia JA, Livingston JN, Lockwood DH (1985) Insulin resistance: receptor and post-binding defects in human obesity and non-insulin dependent diabetes mellitus. Am J Med 979 [Suppl 2B]: 13-22

Received: 30 June 1988

and in revised form: 28 Oktober 1988

Dr. P.Arner

Department of Medicine

Huddinge Hospital

S-141 86 Huddinge

Sweden 